\title{
MÁGNESES ERÖVEL TÖRTÉNŐ FELÜLETHENGERLÉS HATÁSA A FELÜLETÉRDESSÉGRE ÉS A KORRÓZIÓRA C45 ACÉLON
}

\section{INFLUENCE OF MAGNETIC ASSISTED BALL BURNISHING ON THE ROUGHNESS AND CORROSION RESISTANCE OF C45 STEEL}

\author{
Kovács Zsolt Ferenc ${ }^{1,3^{*}}$, Károly Dóra ${ }^{2}$, Károly Péter Balázs ${ }^{1}$, Kemény Dávid ${ }^{2}$, Kodácsy János ${ }^{3}$, \\ Viharos Zsolt János ${ }^{3,4}$ \\ ${ }^{1}$ Budapesti Műszaki és Gazdaságtudományi Egyetem, Gyártástudomány és -technológia Tanszék, \\ Magyarország, 1111. Budapest, Müegyetem rkp. 3. kovacszs@manuf.bme.hu \\ 2 Budapesti Müszaki és Gazdaságtudományi Egyetem, Anyagtudomány és Technológia Tanszék, \\ Magyarország, 1111 Budapest, XI. Műegyetem rkp. 3. kdora@eik.bme.hu \\ ${ }^{3}$ Neumann János Egyetem, GAMF Kar, Jármütechnológia Tanszék, Gazdaságtudományi Kar, \\ Közgazdaságtan és Jog Tanszék, Magyarország, H-6000 Kecskemét, Izsáki út 10. kovacs.zsolt@gamf.uni- \\ neumann.hu, kodacsy.janos@gamf.uni-neumann.hu \\ ${ }^{4}$ Számítástechnikai és Automatizálási Kutatóintézet, Magyarország, H-1111 Budapest, Kende u. 13-17. \\ viharos.zsolt@sztaki.hu \\ https://doi.org/10.47833/2020.2.ENG.005
}

\section{Kulcsszavak: \\ felülethengerlés \\ mágnesesség \\ korrózió \\ finiselés}

\section{Keywords:}

ball burnishing

magnetism

corrosion

finishing

\section{Cikktörténet:}

Beérkezett 2020. június 10.

Átdolgozva 2020. június 20.

Elfogadva 2020. július 1.

\begin{abstract}
Összefoglalás
A fémek korrózióállóságának növelése már nem csak felületi védörétegek felvitelével valósulhat meg, sőt, gazdaságosabb, hatékonyabb eljárások is alkalmazhatók, melyek közvetlen a gyártási folyamathoz kötödve valósulhatnak meg. Ebben a cikkben a mágneses síkfelülethengerelés korrózióálóságra gyakorolt hatását vizsgálták a szerzők. Alkalmazásával a további utómunkálatok költsége jelentősen csökkenthető, ugyanakkor a kezelt felületek keménysége és élettartama jelentősen nö, míg felületi érdessége számottevően csökken.
\end{abstract}

Abstract
To increase the corrosion resistance of metals is not only
achieved by applying surface protective coatings, but also can
be used more economical, more efficient processes which are
directly related to the manufacturing process, like the magnetic
assisted ball burnishing. In this article, the authors investigated
the effect of magnetic assisted ball burnishing on the corrosion.
The cost of further post-processing can be significantly reduced,
the hardness and lifetime of the treated surfaces are significantly
increased, while surface roughness is significantly reduced by
the magnetic assisted ball burnishing tool.

\footnotetext{
* Kapcsolattartó szerző: E-mail: kovacs.zsolt@gamf.uni-neumann.hu
} 


\section{Bevezetés}

A korrózió lassítására, megakadályozására számos kísérlet és megoldás is született, melyek képesek ténylegesen is védeni a korróziónak kitett eszközöket. Ezek a módszerek rendszerint valamilyen bevonat, a felületre felvitt védöréteg alkalmazásán alapulnak. A modern mérnöki tudomány azonban kutatja azokat az eljárásokat, ahol a felületvédő anyagok utólagos alkalmazása helyett maga a gyártástechnológia nyújthat megoldást a korrózió elleni védelemben. Ilyen eredményt lehet elérni a felületi képlékeny alakváltozást okozó eljárásokkal.

A cikkünkben egy, a gyártásban még korántsem elterjedt, a mágneses síkfelülethengerlő szerszám alkalmazását vizsgáljuk, mely az eddigi adatok alapján rendkívül ígéretes eljárást biztosít a korrózió elleni védekezésben.

\subsection{Az állandó mágneses síkfelület-hengerlő berendezés ismertetése}

A felülethengerlés előnyei abból adódnak, hogy a megmunkálás során a szerszám az anyag folyáshatáránál nagyobb terhelést fejt ki az anyagra, ezáltal a felületi réteg megfolyik, és az érdességcsúcsok elkezdik feltölteni a völgyeket. Mivel a felületi réteg képlékenyen alakváltozik, a keménysége nő.

A mágneses síkfelület-hengerlés elve az, hogy a szerszám adott fordulatszámmal egyenes vonalú vagy adott pálya szerinti mozgást végezve végighalad a munkadarab felületén.

A kísérlet során használt szerszám egy állandó mágnest tartalmazó, CNC-marógépbe befogható szerszám, ennek köszönhetően a megmunkálást követően a munkadarab befejező müveletét rögtön a marógépben is elvégezhetjük, amivel jelentős idő- és pénzmegtakarítás érhető el. Felépítése egyszerü, külön karbantartást nem igényel (1. ábra).

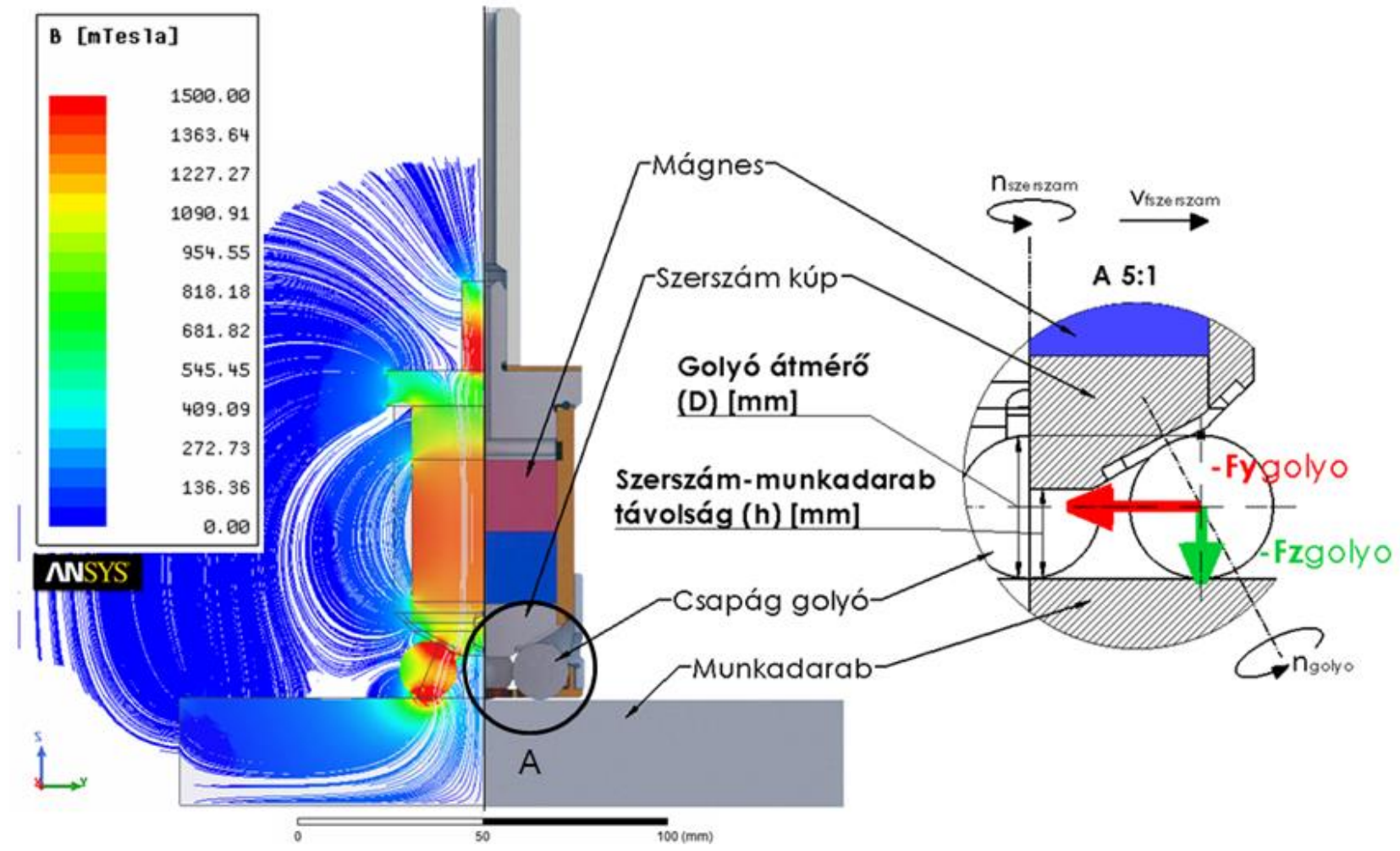

1. ábra. Az állandó mágneses síkfelület-hengerlő szerszám felépítése és müködési elve

\subsection{Korrózió kialakulása}

Az MSZ EN ISO 8044:2016 szabvány szerint a korrózió a fém és környezete közötti fizikaikémiai kölcsönhatás, amelynek következtében a fém tulajdonságai megváltoznak, és gyakran bekövetkezik a fém, a környezet, illetve az ezekböl álló műszaki rendszer funkcionális jellemzőinek a romlása [1]. 
A reakció lefolyási módja szerint az alábbi csoportokba sorolhatjuk a korróziós folyamatokat [2, 3]:

- kémiai korrózió;

- elektrokémiai korrózió.

\subsubsection{A felületi érdesség hatása a korrózióra}

A mérnöki tudományokban általánosan elfogadott tény, hogy a felületi érdességi értékek szoros összefüggésben állnak a korrózióállósággal, mivel a kontaktfelület növekedésével a korrózió sebessége is növekedni fog [4-6].

Egy 2006-os cikkben Honess és társai a felületi minőség és a korrózióálló acélok korrózióállóságáról írtak. Szerintük, amennyiben az átlagos érdesség nagyobb mint $1 \mu \mathrm{m}$, a felületen elég mély barázdák és gödrök jönnek létre ahhoz, hogy a kloridionok abban összegyüljenek. Amennyiben a felületen az átlagos érdességet 0,5 $\mu \mathrm{m}$ alá tudjuk szorítani, annak az esélye, hogy a fentebb említett kloridionok meg tudnak tapadni a gödrökben, jelentősen csökken, és a jelenség szinte megszünik [4].

Asma és munkatársai 2011-es tanulmányukban vizsgálták a felületi érdességi értékek összefüggését a korrózióálló képességekkel C22E acélon, szén-dioxid környezetben. A kísérlet során a mintadarabokat különböző szemcseméretű szilícium-karbid csiszolópapírokkal munkálták készre. Kimutatták, hogy az egyre finomabb csiszolópapírokkal megmunkált mintadarabok egyre jobb korrózióállóssági képességeket mutattak, azonban az eltérések nagyon kicsik, ezért nem tekintik őket szignifikánsnak [5].

Hryniewicz és Rokosz 2004-es kísérletében, C45 típusú acélon vizsgálta a felületi érdesség és a korrózióállóság összefüggését. A mintadarabok felületét különböző szemcsenagyságú csiszolópapírokkal csiszolták, illetve polírozták. Az elkészült mintákat 3\%-os és $0,03 \%$-os nátriumklorid oldatban vizsgálták. A sokkal agresszívebb 3\%-os oldat, esetében a legdurvább, 180-as papír, és a lefinomabb, 4000-es, csiszolás között a különbség közel háromszoros volt korrózióállóság terén, a finomabb javára. A 0,03\%-os oldat esetében is jelentős, 1,6 szoros javulást értek el a legfinomabb csiszolóval, a legdurvábbhoz képest [6].

\subsubsection{A hengerlés hatása a korrózióra}

Az előző pontban bemutatott tanulmányok és kísérletek mind abrazív megmunkálással készített felületekre vonatkoztak. A hengerlés mint képlékeny hidegalakítási felületjavító eljárás ezektöl jelentősen különbözik. Alapvető eltérés, hogy a hengerlés során forgácsleválasztás nem történik, így az anyag szemcseszerkezete nem sérül olyan mértékben, mint az abrazív megmunkálások során.

Salahshoor 2017-es tanulmányában vizsgálta egy forgásszimmetrikus alkatrész, MgCa0,8 ötvözet, korrózióállósága növelésének lehetőségét golyós hengerléssel. Ez a vizsgálat azért volt szükséges, mert ez az implantátumok körében igen jó tulajdonságú ötvözet az emberi szervezetben nagyon gyorsan korrodálódik, így az anyag használata mind gazdaságilag nem kielégítő, mind újabb műtétnek teszik ki a pácienst . A vizsgálatban három különböző vágási sebességgel síkmart és három különböző hengerlőerővel hengerelt mintadarabot készített. $A$ mintadarabok korrózióállóságát Hank-féle kiegyenlített sóoldatos vizsgálattal hasonlította össze. A teljeség igénye nélkül az eredményei a következők voltak [7]:

- a forgácsolással készre munkált mintákkal szemben a hengerelt mintákon sokkal kevesebb és egyenletesebb korróziótermék jött létre;

- a hengerlési erő növelésével a mintadarabokon egyre nagyobb mértékű korrózió ment végbe.

Saldaña-Robles és társai a hengerlés hatását vizsgálták a felületi érdességre, a felületi keménységre és a korrózióállóságra. Az alapanyag minden esetben C45 anyagú, kör keresztmetszetü rúdacél volt, amelyek palástfelületeit munkálták meg esztergálással. A korrózióállóságot egy esztergált mintadarabon és az optimális, vagyis a legkisebb átlagos felületi érdességü és legnagyobb keménységü, hengerelt mintadarabon hasonlították össze. Következtetéseik alapján a hengerelt mintadarab korróziós ellenállása nagyobb volt, mint az esztergált mintáé [8]. 
Hryniewicz és Rokosz egy másik tanulmányában elvégeztek egy hasonló kísérletet, melyben C45 acél mintadarabok görgős hengerlésének a hatását vizsgálták a korrózióállóságra. Összehasonlították a görgőzött darabokat polírozott mintákkal. A görgős hengerlés nem csupán a felületi érdesség jelentős javulását eredményezte, hanem jelentősen javította a korrózióállóságot is. A polírozott mintákat párosították az azonos felületi érdességü, hengerelt mintákkal, és összevetve a korrózióállóságot az alábbi eredményeket kapták [9]:

- 500-as szemcseméretű papír és vele felületi érdességben megegyező hengerelt minta között, 3\%-os nátrium-klorid oldatban, 17-szeres különbség adódott a korrózió sebességében a hengerlés javára, míg 0,3\%-os oldatban 5,5-es különbség adódott szintén a hengerlés javára;

- 4000-es szemcseméretű papír és vele felületi érdességben megegyező hengerelt minta között, 3\%-os nátrium-klorid oldatban, 3-szoros különbség adódott a korrózió sebességében a hengerlés javára, míg 0,3\%-os oldatban 1,6-es különbség adódott szintén a hengerlés javára.

\section{A kísérleti munka ismertetése}

A vizsgálatot tekintve nem szempont korrózióálló anyagot használata, mivel a cél nem egy korrózióálló anyag létrehozása, vagy fejlesztése, hanem csupán a korrózióállóság vizsgálata különböző hengerlési stratégiák és megmunkálási feltételek mellett. A kiválasztott anyag általános rendeltetésü, ötvözetlen, nemesíthető acél, az anyagminőség: C45.

Fontos kérdés, hogy a légköri korrózióval szemben meg lehet-e védeni vagy jelentős mértékben javítani hengerléssel a korrózióállóságát, növelve ezzel az élettartamát egy nem korrózióálló acélnak.

\subsection{Kísérleti körülmények}

Az előgyártmányok melegen hengerelt, $200 \mathrm{~mm}$ hosszú, $100 \mathrm{~mm}$ széles és $15 \mathrm{~mm}$ magas téglatestek, melyek egy nagyobb táblából gondosan lettek kivágva, úgy, hogy a vágás közben jelentős hőhatás ne keletkezzen, ami befolyásolhatná a későbbi vizsgálatokat. A kísérletek kísérletterv alapján különböző megmunkálási paraméterekkel és eljárásokkal (összesen 9 hengerelt és 3 csak forgácsolt minta) készültek. Mindegyik minta elözetesen köszörüléssel vagy marással volt elömunkálva a hengerléshez. A marás során homlokmarót használtunk, melyben SECO APMX160408TR-M14 MP2500 típusú lapkák voltak, míg a köszörülést síkköszörügépen végeztük. A felületek készítésekor a cél különböző érdességü felületek előállítása volt. Ezt az eredményt sikerült is elérni.

Az elökészítő folyamatok után következett a hengerlési fázis, ahol szintén CNC-marógép volt erre a feladatra alkalmas. A hengerlés összeállításához Taguchi szerinti kísérlettervezési módszert alkalmaztunk, a MiniTab18 szoftver segítségével. A kísérlettervnek 3 szintje és 4 faktora van. Az 1. táblázat mutatja az egyes faktorok változását, ahol a változók a következők voltak:

A: Előmunkált felület érdessége, $\mathrm{Ra}(\mu \mathrm{m}): \sim 0,8 ; \sim 1,6 ; \sim 2,4$.

B: Elötolási sebesség, $v_{f}(\mathrm{~mm} / \mathrm{min}): 10 ; 30 ; 50$.

C: Hengerlési sebesség, $v_{\mathrm{h}}(\mathrm{m} / \mathrm{min}): 20 ; 50 ; 80$.

D: Hengerlés mértéke, (\%): 100; 150; 200.

1. táblázat. A Taguchi-módszer szerinti kísérletterv

\begin{tabular}{ccccc}
\hline \multirow{2}{*}{ Szintek } & \multicolumn{4}{c}{ Faktorok } \\
\cline { 2 - 5 } & $\mathbf{A}-\mathbf{R a}(\boldsymbol{\mu m})$ & $\mathbf{B}-\boldsymbol{v}_{\mathbf{f}}(\mathbf{m m} \mathbf{m i n})$ & $\mathbf{C}-\boldsymbol{V}_{\mathbf{h}}(\mathbf{m} / \mathbf{m i n})$ & $\mathbf{D}-(\%)$ \\
\hline $\mathbf{1}$ & 0,8 & 10 & 20 & 100 \\
$\mathbf{2}$ & 0,8 & 30 & 50 & 150 \\
$\mathbf{3}$ & 0,8 & 50 & 80 & 200 \\
$\mathbf{4}$ & 1,6 & 10 & 50 & 200 \\
$\mathbf{5}$ & 1,6 & 30 & 80 & 100 \\
$\mathbf{6}$ & 1,6 & 50 & 20 & 150 \\
$\mathbf{7}$ & 2,4 & 10 & 80 & 150 \\
$\mathbf{8}$ & 2,4 & 30 & 20 & 200 \\
$\mathbf{9}$ & 2,4 & 50 & 50 & 100 \\
\hline
\end{tabular}


A hengerlés mértéke alatt a szerszámpálya szélessége értendő aszerint, hogy a szerszám milyen széles felületet hengerel. Így a $100 \%$ az egyenest, a $150 \%$ a kis ciklois, a $200 \%$ a nagy ciklois pályát jelenti. Az elkészült mintadarabokon jól láthatóak a hengerlés nyomai a 2 . ábrán.

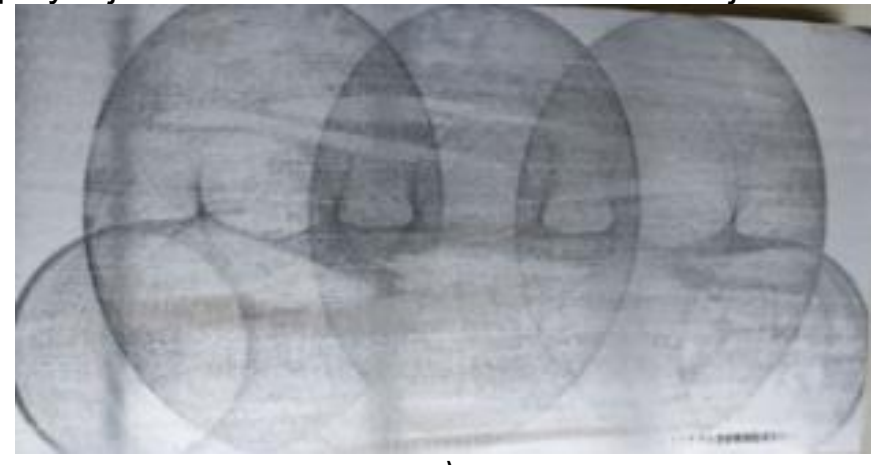

a)

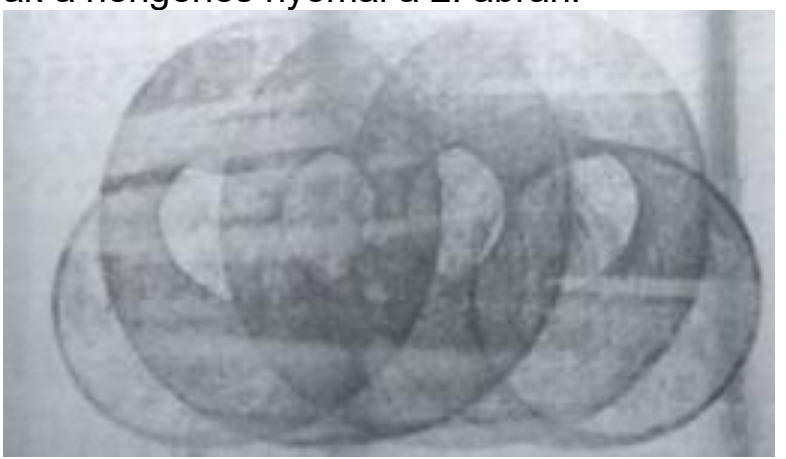

b)

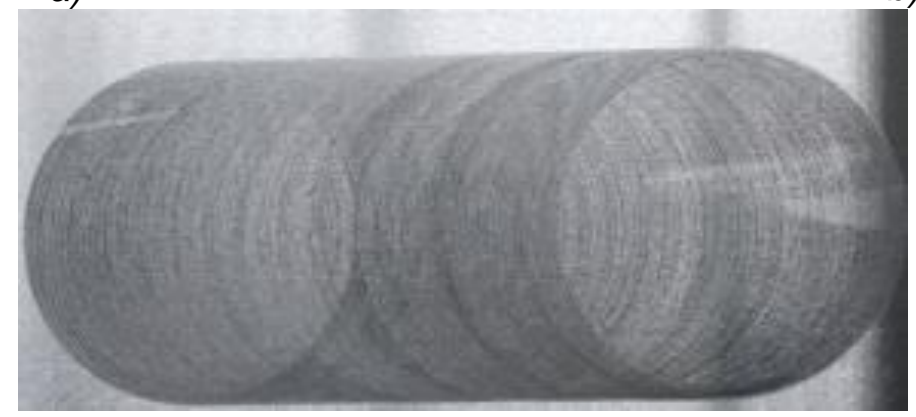

c)

2. ábra A hengerlés nyomai a mintákon a) nagy ciklois b) kis ciklois c) egyenes

\section{A kísérlet eredményei}

A megmunkált felületeken a korróziós vizsgálatokat BioLogic SP-150 potenciosztát és ECLab szoftvert használtunk, míg a pásztázó elektronmikroszkópos felvételek készítésére Zeiss EVO MA10 pásztázó elektronmikroszkópot használtunk, a mérések során 20 kV-os gyorsítófeszültséget használtunk. Az érdességmérést MITUTOYO Formtracer SV-C3000 típusú érdességmérőgépen végeztük.

\subsection{Az érdességmérés eredménye}

Kézi felületiérdesség-mérő segítségével, síkhengerlés előtt és után, átlagos felületi érdességet mértünk. Az érdességi eredmények átlagolása alapján készült a 3 . ábrán látható Ra értékek oszlopdiagramja.

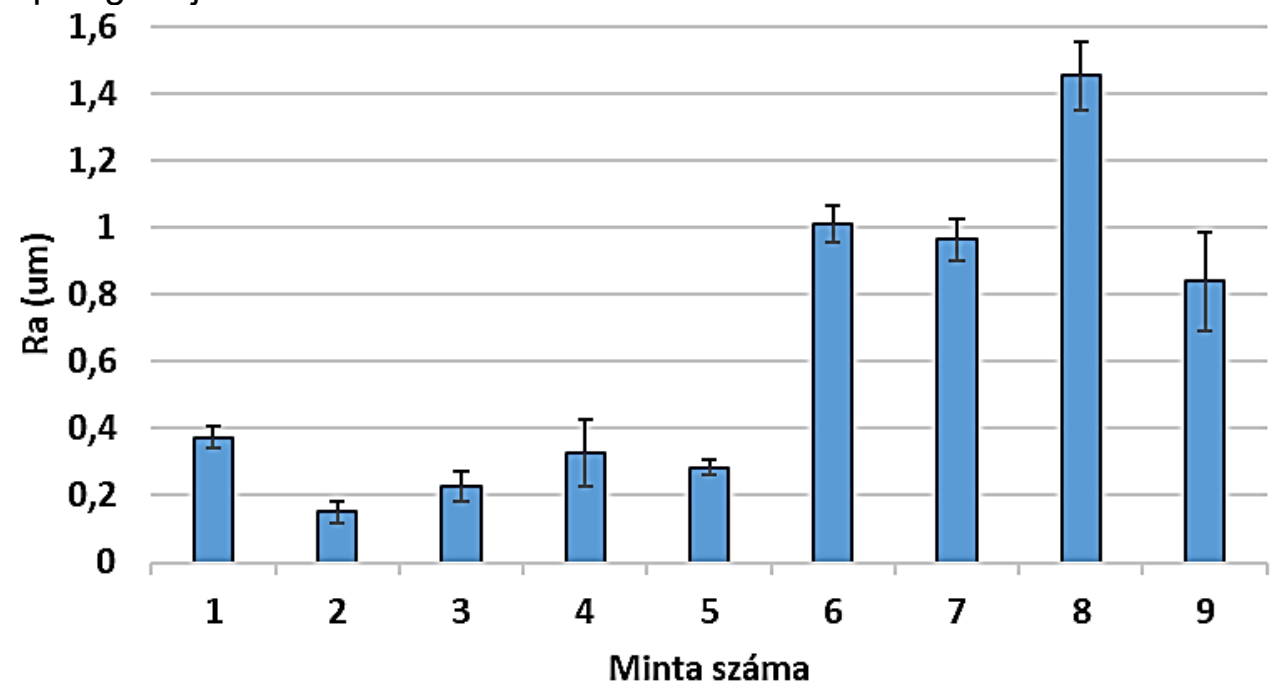

3. ábra A felületi érdesség mérési eredményei 


\section{A 3. ábrán jól látható, hogy az érdességi értékek javultak a kiinduló értékekhez képest.}

\subsection{A korrózió mérése}

Kiértékelés során az ASTM G102 szabvány iránymutatását használtuk. A korróziós áramértékek kinyerhetőek galvánelemes és polarizációs mérések segítségével, beleértve a Tafel extrapolációsvagy polarizációs ellenállás méréseket. Első lépésként át kell váltanunk a mért vagy becsült áramerősséget áramsűrüségre. Ezt az összáram és az elektróda oldatba mártott geometriai felszínének hányadosaként kaphatjuk meg. Feltesszük, hogy az áram egyenletesen oszlik el az elöbb említett terület egészén. Galván párok esetén az anód oldatba merített felületét kell használjuk. A számításhoz szükséges összefüggés (1):

$$
i_{\text {cor }}=\frac{I_{\text {cor }}}{A}
$$

ahol: $i_{\text {cor }}=$ korróziós áramsürüség $\left(\mathrm{yA} / \mathrm{cm}^{2}\right), I_{\text {cor }}=$ össz anódos áram $(\mathrm{yA})$ és $A=$ merített felület $\left(\mathrm{cm}^{2}\right)$. Tiszta elemekre használt ekvivalens tömeg (2):

$$
E W=\frac{W}{n}
$$

ahol: $W=$ az elem atomtömege és $n=$ egy atom oxidációjához szükséges elektronok száma a korróziós folyamatban, ami az elem vegyértéke.

Ötvözetek esetében használandó összefüggés az ekvivalens tömeghez (3):

$$
Q=\sum \frac{n i \cdot f i}{W i}
$$

ahol: $f i=$ az ötvözet i-edik elemének tömege, $W i=$ az ötvözet i-edik elemének atomtömege és $n i=$ az ötvözet i-edik elemének vegyértéke. Így az ekvivalens tömeg ennek reciproka (4):

$$
E W=\frac{1}{\sum \frac{n i \cdot f i}{W i}}
$$

Faraday törvénye használható a korróziós sebesség számításakor (5):

$$
C R=K_{1} \frac{i_{\text {cor }}}{\rho} E W
$$

ahol: $C R$ : $\left(\mathrm{mm} /\right.$ év), $K_{1}=3,27 \cdot 10^{-3}(\mathrm{~mm} \cdot \mathrm{g} / \mu \mathrm{A} \cdot \mathrm{cm} \cdot e ́ v)$ és $\rho=$ sürüség $\left(\mathrm{g} / \mathrm{cm}^{3}\right)$.

A 2. táblázatban látható a kiszámolt egyensúlyi tömeg, a számolt sürüség, a kiértékelésből kapott korróziós áram és a sztereomikroszkópos képekröl (4. ábra) a korrózió után lemért pontos felület.

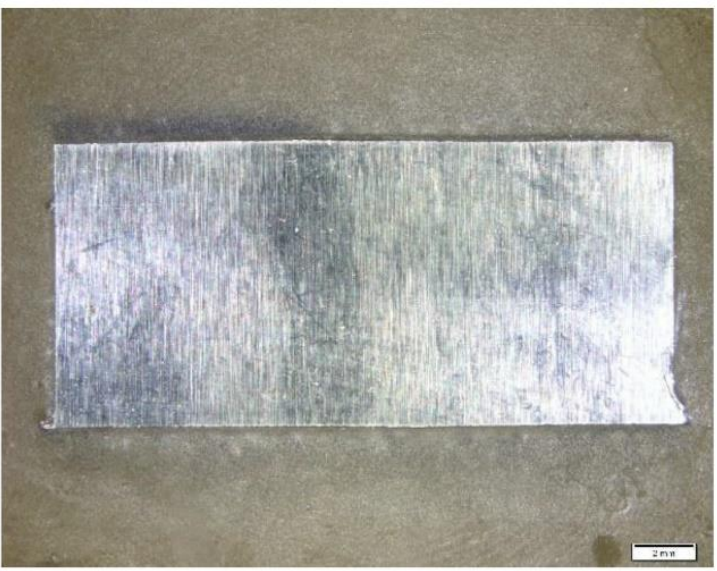

\begin{tabular}{|c|c|c|c|c|c|c|}
\hline $\begin{array}{l}\text { Minta } \\
\text { száma }\end{array}$ & $E w(-)$ & $\rho\left(\mathrm{g} / \mathrm{cm}^{3}\right)$ & $I_{\text {cor }}(\mu \mathrm{A})$ & $A\left(\mathrm{~mm}^{2}\right)$ & $i_{\text {cor }}\left(\mu \mathrm{A} / \mathrm{cm}^{2}\right)$ & $C R$ (mm/év) \\
\hline 1 & & & 6977,533 & 239,829 & 29,094 & 24,598 \\
\hline 2 & & & 7270,618 & 207,698 & 35,006 & 29,596 \\
\hline 3 & & & 7647,384 & 194,627 & 39,293 & 33,220 \\
\hline 4 & & & 3914,594 & 194,164 & 20,161 & 17,045 \\
\hline 5 & 19,293 & 7,462 & 6348,125 & 179,147 & 35,435 & 29,959 \\
\hline 6 & & & 6731,190 & 196,744 & 34,213 & 28,926 \\
\hline 7 & & & 4534,413 & 217,317 & 20,865 & 17,641 \\
\hline 8 & & & 6986,236 & 235,616 & 29,651 & 25,069 \\
\hline
\end{tabular}

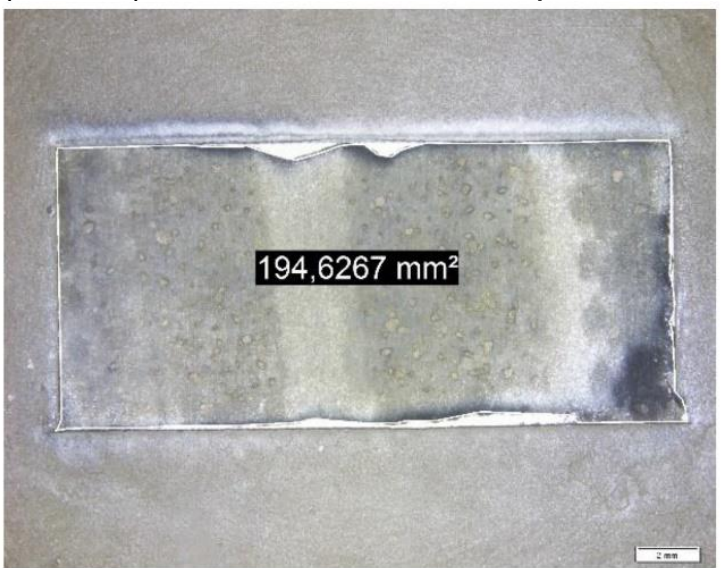

4. ábra A 3-as minta felülete sztereomikroszkóppal, balra: korrózió előtt, jobbra: korrózió után felületméréssel

\section{2. táblázat. Korróziós sebesség értékek a beágyazott minták 1 órás mérése után}


9

5830,740

194,261

30,015

25,376

Magát a korróziós áramot a berendezés által kirajzolt Tafel görbék alapján kaphatjuk meg (4. ábra). A görbe lefutó és felfutó szárának egyenes részére kell érintőt illeszteni és az általuk kimetszett pont adja a korróziós áramot.

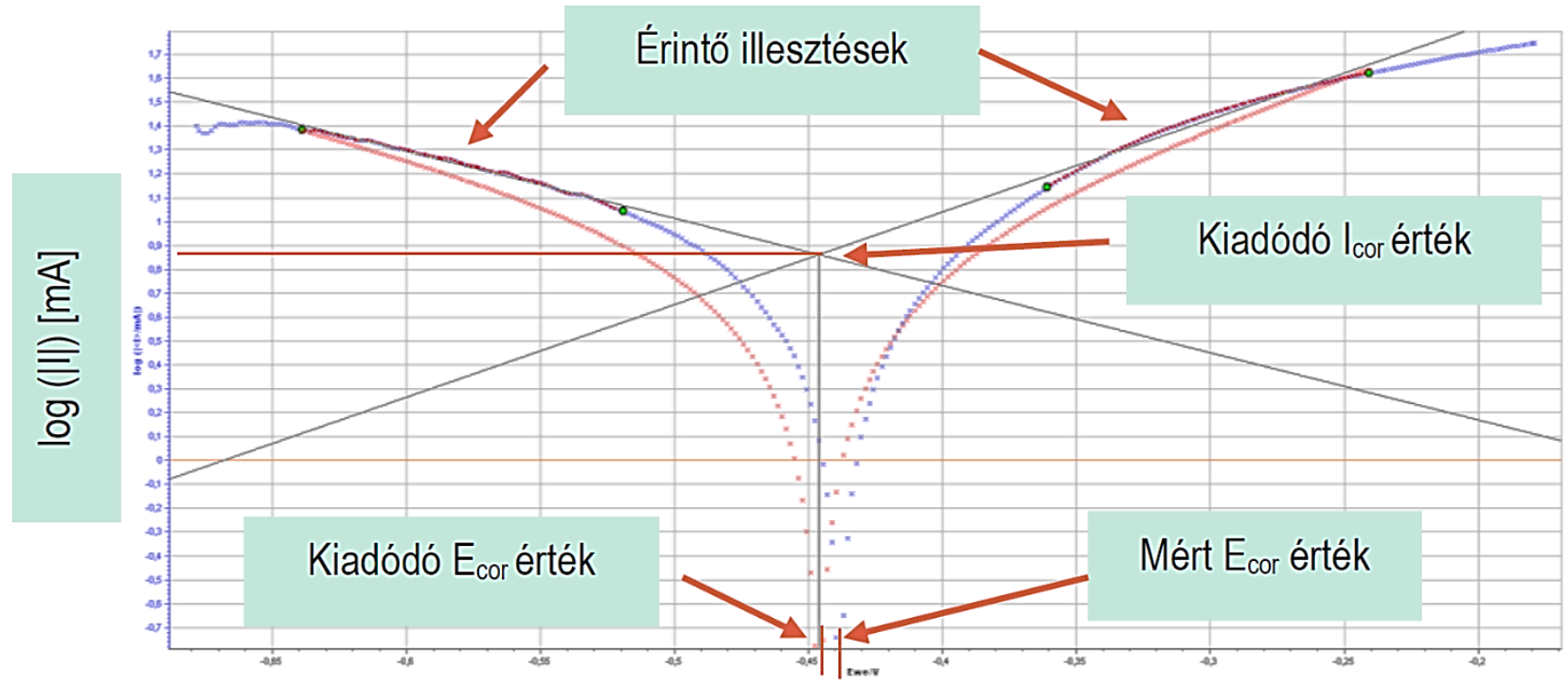

Ewe $[\mathrm{mV}]$

4. ábra Tafel görbe a fontos részek megjelölésével

A kapott eredmények alapján a korróziósebesség értékek javultak a hengerlés hatására. $A$ mintákon az egy órás mérés után a 5. ábrán láthat korrózió sebességeket mértük.

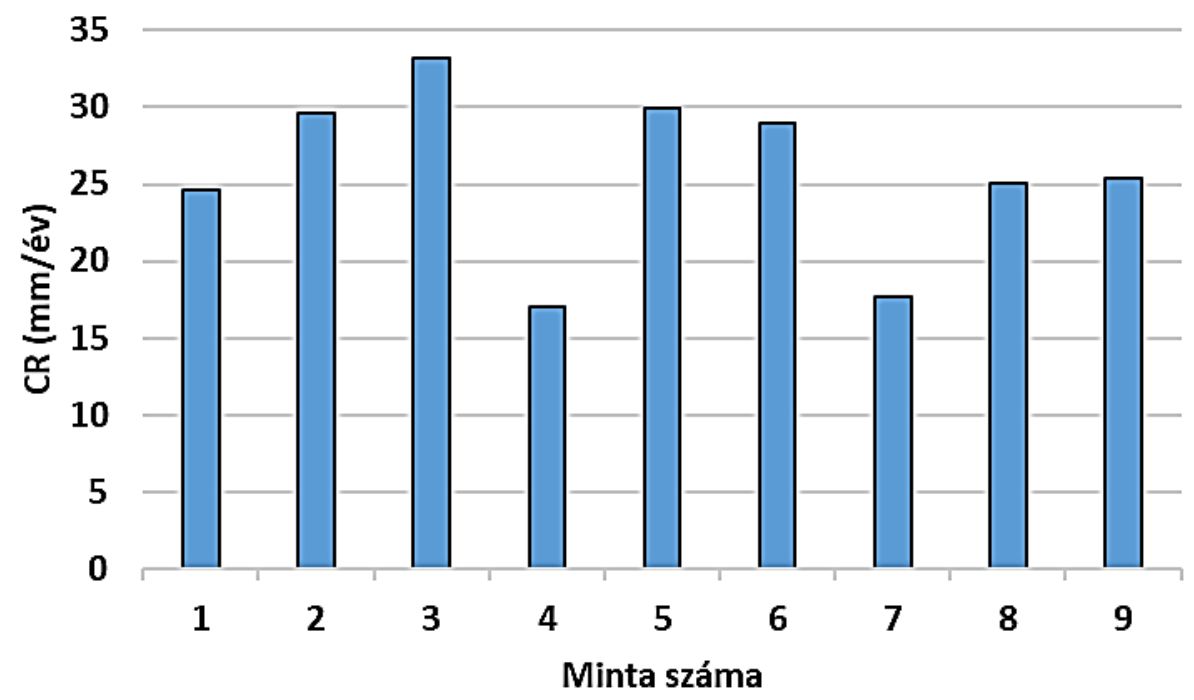

5. ábra Korrózió sebesség az 1 órás mérés után

\section{4. Összegzés}

A hengerelt felületeken kisebb mértékben alakultak ki korrózió és sokkal egyenletesebb az általános korrózió eloszlása a hengerelt felületeken. Továbbá a kevésbé hengerelt 1-es és a nagy százalékban hengerelt 7-es mintát nézve, láthatjuk, hogy a 7-es mintán nagy részek még ellenálltak a korróziónak, amíg az 1-es minta teljes felületén megfigyelhető az egyenletes korrózió (6. ábra).

Mindebböl arra lehet következtetni, hogy a hengerlés mértéke (áthengerlések száma) befolyással van a felület korrózióállóságára. 


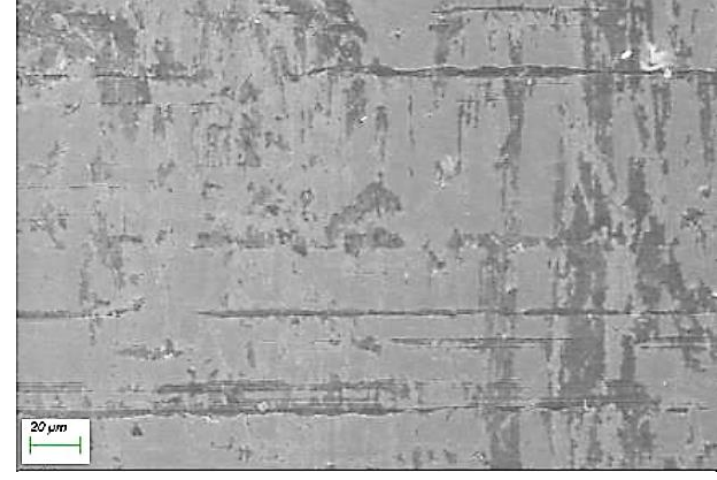

1-es minta korrózió elött $(N=1000 \times)$

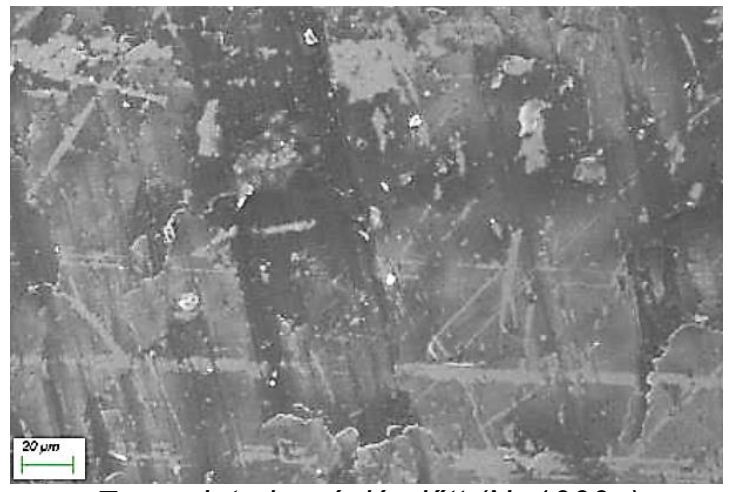

7-es minta korrózió elött $(N=1000 \times)$

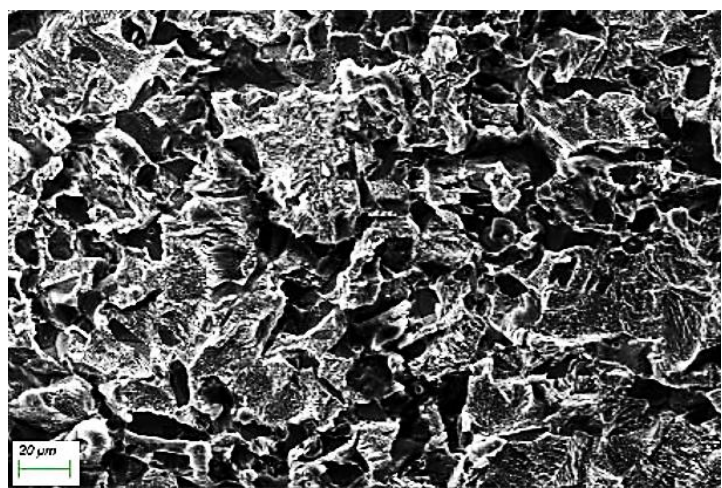

1-es minta korrózió után $(N=1000 \times)$

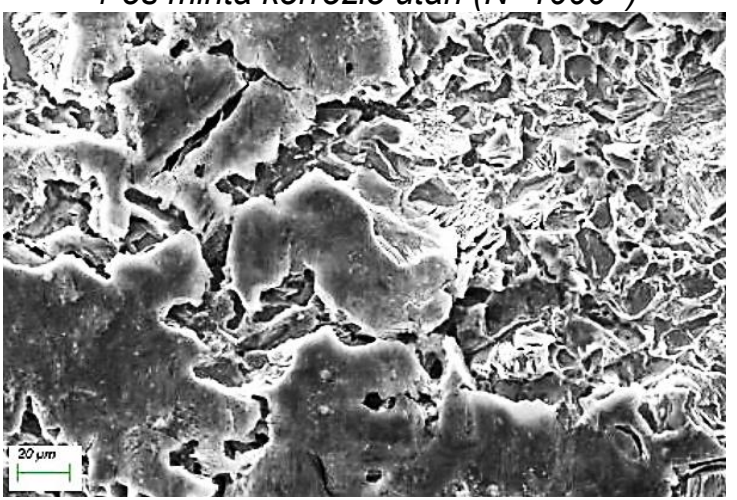

7-es minta korrózió után $(N=1000 \times)$

6. ábra 1-es és 7-es minta felülete, SEM képek.

A Taguchi-módszerrel kiértékelt optimális technológiai paraméterek a korrózióállóság növelése szempontjából a (A3-B1-C2-D3) 2,4 $\mu \mathrm{m}$ felületi érdesség, $10 \mathrm{~mm} / \mathrm{min}$ elötolás, $50 \mathrm{~m} / \mathrm{min}$ hengerlési sebesség és $200 \%$ nagy ciklois pálya alkalmazásával érhető el.

\section{Köszönetnyilvánítás}

Köszönettel tartozunk a kutatás támogatásáért, amely az EFOP-3.6.1-16-2016-00006 „A kutatási potenciál fejlesztése és bővítése a Neumann János Egyetemen” pályázat keretében valósult meg. A projekt a Magyar Állam és az Európai Unió támogatásával, az Európai Szociális Alap társfinanszírozásával, a Széchenyi 2020 program keretében valósul meg. A kutatást részben "Kutatások az ipari digitalizáció által nyújtott potenciál minőségi kiaknázására" című ED_18-2-20180006 támogatás tette lehetővé.

\section{Irodalomjegyzék}

[1] MSZ EN ISO 8044:2016: Fémek és ötvözetek korróziója. Alapvető szakkifejezések és fogalommeghatározások

[2] A.S. Alcantara, E.R. Fábián, M. Furkó, É. Fazakas, J. Dobránszky, T. Berecz: Corrosion resistance of TIG welded joints of stainless steels, Materials Science Forum 885 (2017), pp. 190-195

[3] A. S. Abbas, É. Fazakas, T. I. Török: Corrosion studies of steel rebar samples in neutral sodium chloride solution also in the presence of a bio-based (green) inhibitor, International Journal of corrosion and scale inhibition Vol 7 , Issue 1 (2018), pp. 38-47.

[4] C. Hones, A. Harison : Importance of Surface Finish in the Design of Stainless Steel. Importance of Surface Finish in the Design of Stainless Steel, Engineering Utilities. (2006), pp. 14-15.

[5] R. B. A. Nor Asma, P. A. Yuli, C. I. Mokhtar: Study on the Effect of Surface Finish on Corrosion of Carbon Steel in CO2 Environment. Journal of Applied Sciences 11 (2011), pp. 2053-2057.

[6] T. Hryniewicz, K. Rokosz: Corrosion Behaviour of C45 carbon steel after mechanical surface finishing. Proc. of 13th International Metallurgical \& Materials Conference, Metal 2004 (2004), pp. 18-20.

[7] M. Salahshoor, Y.B. Guo, C. Li: Surface Integrity and Corrosion Performance of Biomedical Magnesium-Calcium Alloy Processed by Hybrid Dry Cutting-Finish Burnishing. Procedia Manufacturing 10, (2017), pp. 467-477.

[8] A. Saldaña-Robles, H. Plascencia-Mora, E. Aguilera-Gómez, A. Saldaña-Robles, A. Marquez-Herrera, J. A. Diosdado-De La Peña: Influence of ball-burnishing on roughness, hardness and corrosion resistance of AISI 1045 Steel. Surface \& Coatings Technology, Volume 339, (2018), pp. 191-198.

[9] T. Hryniewicz, K. Rokosz: Corrosion Behaviour of C45 carbon steel after roller burnishing. Journal of Hradec nad Moravici vol. 5, (2005), pp. 24-26. 